\title{
The red coral populations of the gulfs of Naples and Salerno: human impact and deep mass mortalities
}

\author{
G. BAVESTRELLO ${ }^{1 \star}$, M. BO ${ }^{1}$, S. CANESE ${ }^{2}$, R. SANDULLI ${ }^{3}, \&$ R. CATTANEO-VIETTI ${ }^{4}$ \\ ${ }^{1}$ DiSTAV, Università di Genova, Genova, Italy, ${ }^{2}$ ISPRA, Roma, Italy, ${ }^{3}$ DiST, Università di Napoli Parthenope, Napoli, \\ Italy, and ${ }^{4}$ DiSVA, Università Politecnica delle Marche, Ancona, Italy
}

(Received 21 March 2014; accepted 14 fuly 2014)

\begin{abstract}
The existence of deep red coral (Corallium rubrum) banks in the gulfs of Naples and Salerno (South Tyrrhenian Sea, Mediterranean Sea) is well known in historical records due to the heavy coral harvesting that occurred during the 19th and 20th centuries, by both trawling gears and scuba diving. In 2010 and 2012, during two Remotely Operated Vehicle (ROV) surveys on board of the Research Vessel (R/V) Astrea, red coral banks were detected in 16 of the 25 visited localities, between 45 and $150 \mathrm{~m}$ depth. Seven of these banks, located in the inner part of the Gulf of Naples, were already explored in 1918 by a scientific survey reporting the occurrence of red coral. Healthy populations (densities $>90$ colonies $\mathrm{m}^{-2}$ ) were present only around the coasts of the Phlegrean Islands (Ischia and Procida Islands). Very low densities $\left(<5\right.$ colonies $\mathrm{m}^{-2}$ ) or the absence of coral were recorded in all other sites of the Gulf of Naples (including all historical re-visited banks), and a variable percentage of dead colonies was observed. This evidence suggests a huge state of stress likely favoured by the hydrodynamic conditions in the Gulf, enhancing water pollution and sedimentation rate. Finally, the documented high fishing pressure plays a major role in the hard-bottom communities' degradation. A recent mass mortality episode was also recorded along the Amalfi coast, around Li Galli Islands (Gulf of Salerno), at a depth range between 80 and $100 \mathrm{~m}$, where the mortality affected $80 \%$ of the largest colonies, estimated to be around 70 years old. Several possible reasons for this mortality have been hypothesised, such as the formation of local down-welling currents inducing an unusual drop of the thermocline, or sudden warm water emissions (sulphur springs) in an area characterised by important volcanic activities, or local landslides generating turbidity currents along the steep slopes.
\end{abstract}

Keywords: Corallium rubrum, mass mortality, Mediterranean Sea, ROV-imaging

\section{Introduction}

The coralligenous reefs (Ballesteros 2006) are important Mediterranean biodiversity hotspots thanks to their three-dimensional shape and the presence of several habitat-forming species such as sponges, bryozoans, gorgonians and the red coral Corallium rubrum (L., 1758). These organisms act as ecosystem engineers, enhancing the local biodiversity by creating heterogeneity in light intensity, water movement and sedimentation rates and favouring pelagic-benthic coupling processes (Cerrano et al. 2010). At present, in different areas of the western Mediterranean Sea, these assemblages are endangered by several impacts: high silting levels, fishing, scuba diving tourism and the general deterioration of the littoral marine environment.
Moreover, trans-phyletic mass mortality episodes, due to summer heat-waves (caused by sea water temperatures $3-6^{\circ} \mathrm{C}$ above the usual values within $40 \mathrm{~m}$ depth), induced strong stressing conditions in several species that become prone to the proliferation of pathogenic bacteria (Bavestrello et al. 1994; Cerrano et al. 2000; Garrabou et al. 2001; Bally \& Garrabou 2007; Huete-Stauffer et al. 2011). In the western Mediterranean Sea, besides two large-scale episodes in September 1999 (Cerrano et al. 2000; Perez et al. 2000) and July 2003 (Schiaparelli et al. 2007), mass mortalities occurred also in 2002, 2005, 2006, 2008 and 2009 (Garrabou et al. 2009), always impacting shallow-water communities (above $40 \mathrm{~m}$ depth) where the seasonal temperature oscillations are wider.

*Correspondence: Giorgio Bavestrello, DiSTAV, Università degli Studi di Genova, Corso Europa 26, 16132, Genoa, Italy. Tel: +39 010 3538031. Email: giorgio.bavestrello@unige.it 
The list of the organisms struck is long and includes the red coral, a species of EU interest (Annex V of the European Union Habitats Directive) that can constitute facies with very high densities up to a depth of about 120-150 m (Rossi et al. 2008). In addition, the long history of commercial exploitation of this species, coupled with its sensitivity to environmental stresses and its slow growth rate (Cattaneo-Vietti \& Bavestrello 2010; Tsounis et al. 2010), has induced preoccupation about its fate (Bruckner 2009, 2014; Bussoletti et al. 2010).

In Italy, the harvesting of red coral is carried out only by professional scuba divers below $50 \mathrm{~m}$ depth, and trawling devices have been completely forbidden since 1994. The harvesting of branches less than $10 \mathrm{~mm}$ in basal diameter is not permitted. Particularly in Sardinia, a specific regional law regulates the fishing effort by limiting the number of licenses, fishing periods and areas.

In the gulfs of Naples and Salerno (southern Tyrrhenian Sea), the occurrence of red coral banks is historically documented since they have been commercially exploited for a long time on cliffs or shoals down to $200 \mathrm{~m}$ depth. Already in 1785, Cavolini provided information on some fishing areas at Vico Equense, while Costa (1871) reported the presence of the coral between Capri and Punta Campanella. Lo Bianco (1909) indicated numerous coral banks, the so-called "coralliere", 150-200 m depth, along sea-lanes starting from Naples towards Capri and Torre del Greco in the southern area of the Gulf.

At the beginning of the 20th century, the largest colonies collected on these banks, $35 \mathrm{~cm}$ high and $30 \mathrm{~cm}$ wide, were sold by the Zoological Station of Naples to several museums around the world (Mazzarelli \& Mazzarelli 1918).

The most comprehensive study on these coral banks is the one by Mazzarelli and Mazzarelli (1918) who provided a detailed map with 23 locations exploited by fishermen in the Gulf of Naples. Despite this, no quantitative data were given on the entity of the coral fishery: probably several hundred kilos per year according to Lo Bianco (1909).

According to Mazzarelli and Mazzarelli (1918), the best coral, according to shape and size of the colonies, was obtained in the shoal named Pampano. Some vernacular names of the banks, though, are considered nowadays indicative of coral abundance: for example, the Mano di dentro shoal (the hand inside shoal) was named after fishermen used to state that in this site "sinking the hand in the sea was enough to drag out a handful of coral branches" (Mazzarelli \& Mazzarelli 1918). These coral populations were heavily harvested during the 19th and 20th centuries with trawling gear, and the state of conservation of some of them was already compromised in the early decades of the 20th century: according to Mazzarelli and Mazzarelli (1918), some banks were "almost completely stripped of their coating of coral", and the harvesting was defined as "wretched" (Mazzarelli 1915) in Punta Licosa (southern limit of the Gulf of Salerno) after 28 dredging operations and a week of work.

Unfortunately, for nearly a century, no research has been conducted on these banks, still subjected to occasional exploitation by scuba divers. Therefore, both our past and present knowledge of the structure and health status of the Campania red coral banks is still very poor.

This paper aims to give a general assessment of the health status of the deep red coral banks of the Phlegrean Islands (Ischia and Procida Islands) and of the gulfs of Naples and Salerno (South Tyrrhenian Sea, Mediterranean Sea) and to describe the characteristics of localised deep mortality on a bank situated along the Amalfi coast, suggesting possible causative agents.

\section{Materials and methods}

During a series of Remotely Operated Vehicle (ROV) investigations on board of the Research Vessel (R/V) Astrea in the Gulf of Naples and in the Gulf of Salerno in July 2010 and 2012, 25 cliffs and shoals from 45 to $280 \mathrm{~m}$ depth were explored for a total of about 37 hours of video material (Figure 1a). The explored sites were clustered in three localities: Phlegrean Islands (Ischia and Procida), the Gulf of Naples and the Amalfi coast in the Gulf of Salerno. Seven sites of the Gulf of Naples (Table I) matched the historical banks already studied by Mazzarelli and Mazzarelli (1918).

The ROV "Pollux III" was equipped with a digital camera (Nikon D80, 10 megapixel), a strobe (Nikon SB 400), a high-definition (HD) video camera (Sony HDR-HC7) and three jaw grabbers. The ROV carried also a depth sensor, a compass, three parallel laser beams providing a $10-\mathrm{cm}$ scale for the measurement of the frame area and the size of organisms, and an Ultra Short Base Line (USBL) underwater acoustic positioning system, providing every second the ROV's geographic position.

In each video track, the length of which is variable according to the shoal dimension (ranging between 23 and 267 minutes), HD images were taken every minute and those taken on patches of soft bottom were discarded (Table I). A total of 2487 images taken on rocky bottom were successively analysed with Image J software. Each image covers about $1.25 \mathrm{~m}^{2}$ for a total explored rocky area of about $3000 \mathrm{~m}^{2}$. The presence of red coral patches (\% of 

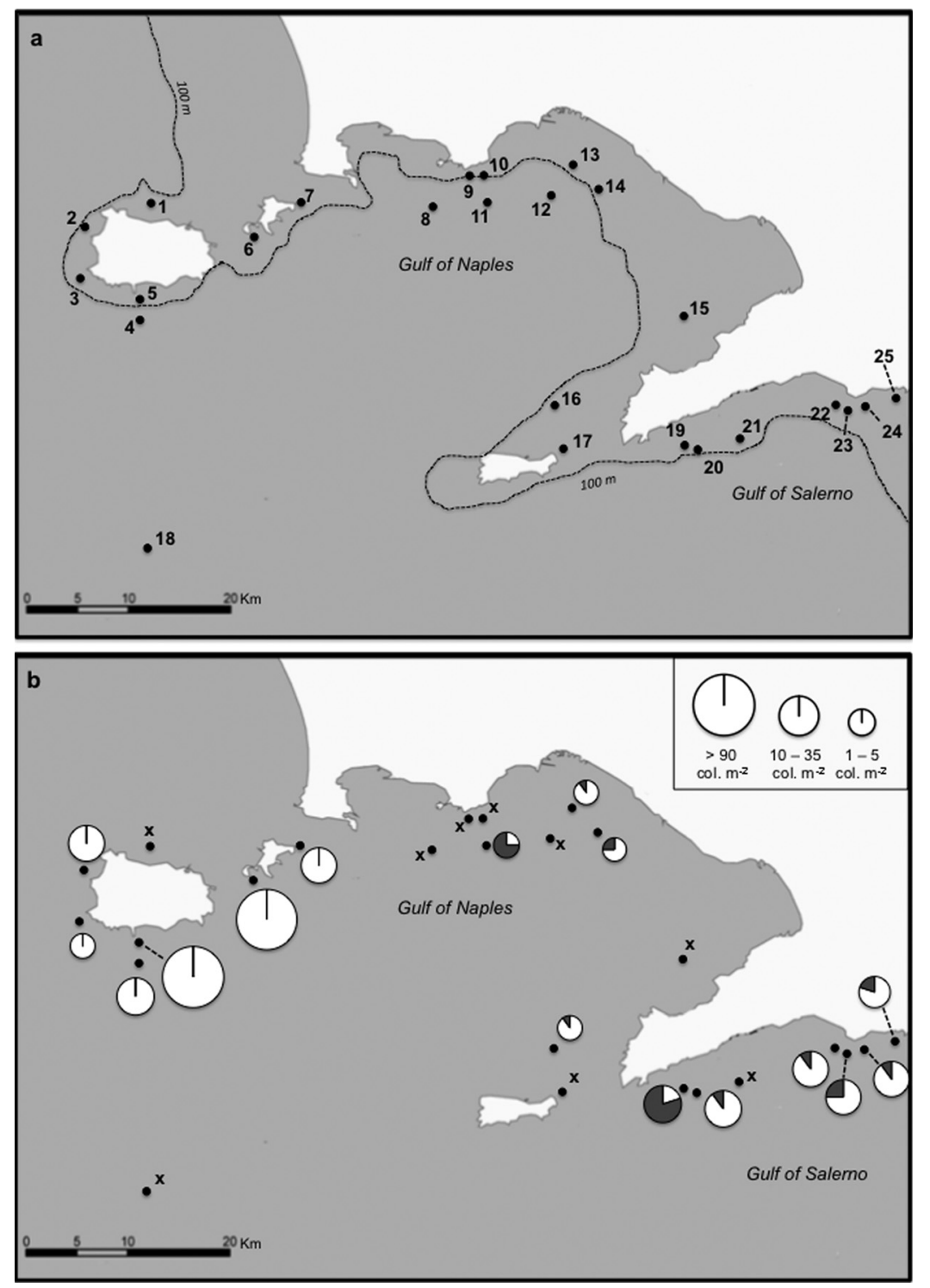

Figure 1. a, Distribution of the explored sites in the study area. The numbers correspond to the list provided in Table I. The sites from 8 to 14, in the inner part of the Gulf of Naples, are those visited by Mazzarelli and Mazzarelli (1918). b, average density and percentage of dead (grey sectors) and healthy (white sectors) colonies. $\mathrm{X}$ indicates the absence of the red coral in the considered site.

images with presence of red coral), the average colony density (expressed as number of colonies $\mathrm{m}^{-2}$ only considering images with red coral presence) and the percentage of living colonies were recorded. Fishing impact was evaluated as the percentage of frames showing lost fishing gear.

A one-way Analysis of Similarity (ANOSIM) was carried out to test for differences in average coral density, percentage occurrence of red coral, percentage of living colonies and percentage of fishing impact among the three studied localities $(\mathrm{PH}$, Phlegrean Islands; GN, Gulf of Naples; AC, Amalfi Coast) considering the entire data set [transformed $\operatorname{sqr}(\mathrm{x})$ data, Bray-Curtis similarity measure, with $n=7,11$ and 7 respectively for $\mathrm{PH}, \mathrm{GN}$ and $\mathrm{AC}]$. Analyses were performed using PAST for Windows version 1.91 (Hammer et al. 2001).

Some dead colonies of Corallium rubrum were collected at Li Galli Island by means of the ROV grabber and were dry preserved to estimate the age of the largest specimens, using the technique of staining the organic matrix found in the axial calcareous skeleton (Marschal et al. 2004).

\section{Results}

During the ROV surveys, red coral was found in 16 of the 25 visited sites (Figure 1a, Table I): colonies 


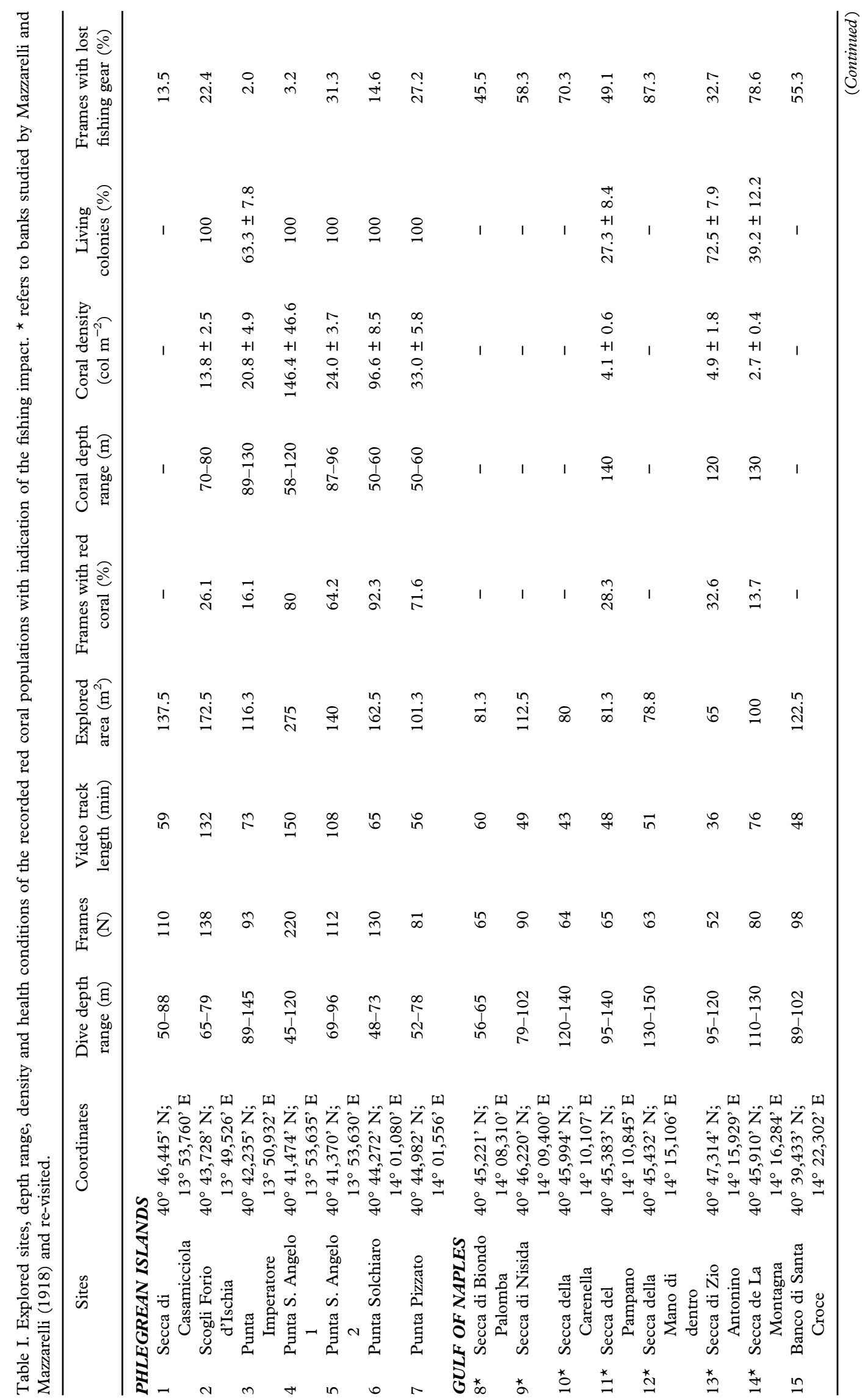




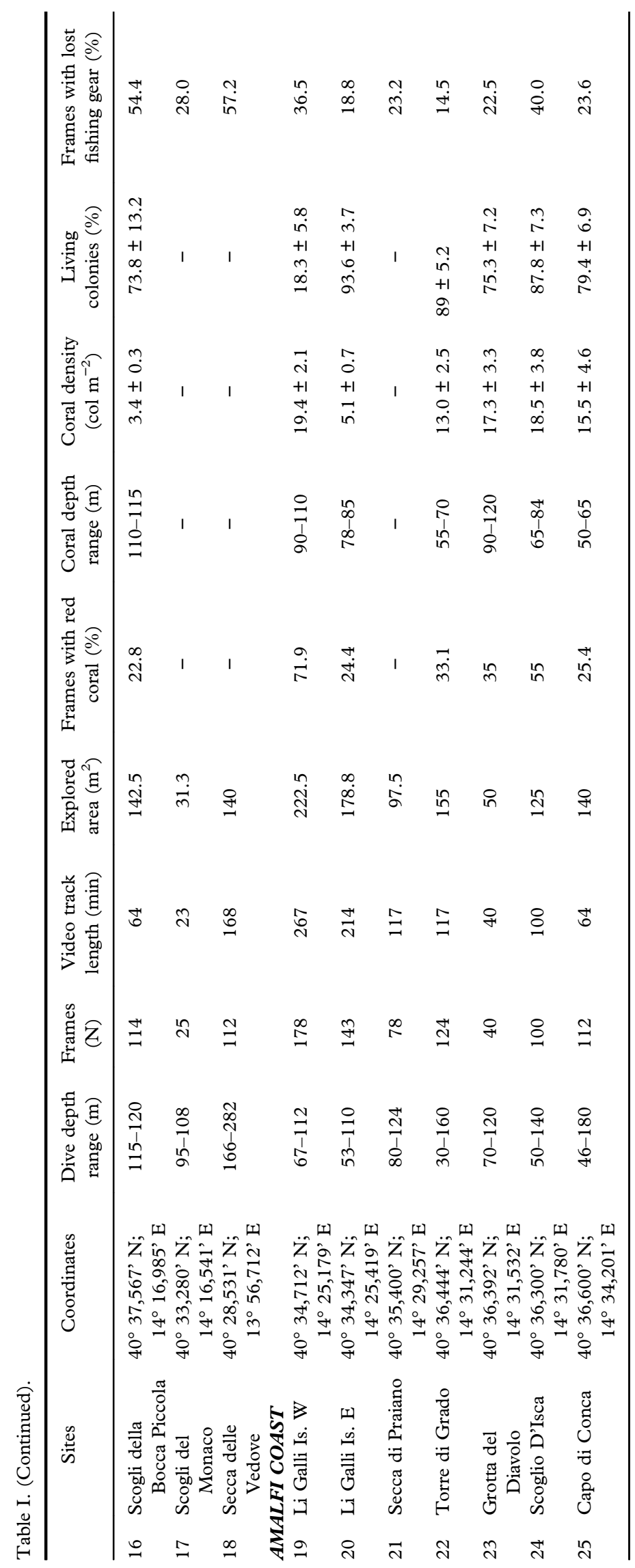


showed the characteristic aggregate distribution, with patches of different extension and density (Table I). Below $150 \mathrm{~m}$ depth, no colonies were found.

In the seven banks reported by Mazzarelli and Mazzarelli (1918) that were re-visited in this study, the red coral is now absent from four sites (Biondo Palomba, Nisida, Carenella and Mano di dentro shoals). In Pampano shoal, a large part of the red coral population was found dead, while in Zio Antonino and La Montagna shoals, the banks show an evident impoverishment, with very low densities of living colonies.

The one-way ANOSIM test performed on the collected data reveals a significant difference among the Gulf of Naples and the other two localities in terms of percentage of red coral occurrence $[p<0.05, R=0.0269,(\mathrm{PH}=\mathrm{AC}>\mathrm{GN})]$, coral density $[p<0.01, R=0.2372,(\mathrm{PH}=\mathrm{AC}>\mathrm{GN})]$, percentage of living colonies $[p<0.05, R=0.2152$, $(\mathrm{PH}=\mathrm{AC}>\mathrm{GN})]$ and percentage of fishing impact $[p<0.001, R=0.4343,(\mathrm{PH}=\mathrm{AC}<\mathrm{GN})]$.

Along the western coast of Ischia Island, red coral was recorded in $16-26 \%$ of the studied frames, with densities ranging from 13 to 20 colonies $\mathrm{m}^{-2}$ (Figure 1b). On the southern coast of Ischia and Procida Islands, the coral presence reached $64-92 \%$ of the studied frames, with densities often up to about 150 colonies $\mathrm{m}^{-2}$ (Figure 1b). In the entire area of the Phlegrean Islands, the percentage of frames including lost fishing gear did not exceed $40 \%$ without any correlation with the percentage of frame with red coral, coral density and percentage of living colonies (Figure 2a).

In the inner portion of the Gulf of Naples, the presence of the species dropped down to $13-32 \%$ of the analysed frames, with densities lower than 5 colonies $\mathrm{m}^{-2}$ (Figure $1 \mathrm{~b}$ ). In this area, up to $87 \%$ of the observed frames showed the presence of abandoned fishing gear on the sea bottom, testifying to heavy fishing activity close to the urban centre of Naples. This gear (nets, long lines and cables) produces a mechanical disturbance of the red coral populations (Figure 3, Table I). In this area, strong negative correlations among the presence of fishing gear $v s$ coral density and percentage of frames with red coral were found (Figure $2 b$ ).

Along the Amalfi coast, the presence of red coral increased to $35-71 \%$ of the studied frames, with densities comprising between 10 and 30 colonies $\mathrm{m}^{-2}$ (Figure 1b, Table I). In this area, no correlations were recorded among these parameters and the percentage of frames including lost gear (Figure 2c).

Healthy populations, showing no dead or damaged colonies, were present only around the Phlegrean Islands. In all other sites, a variable percentage of
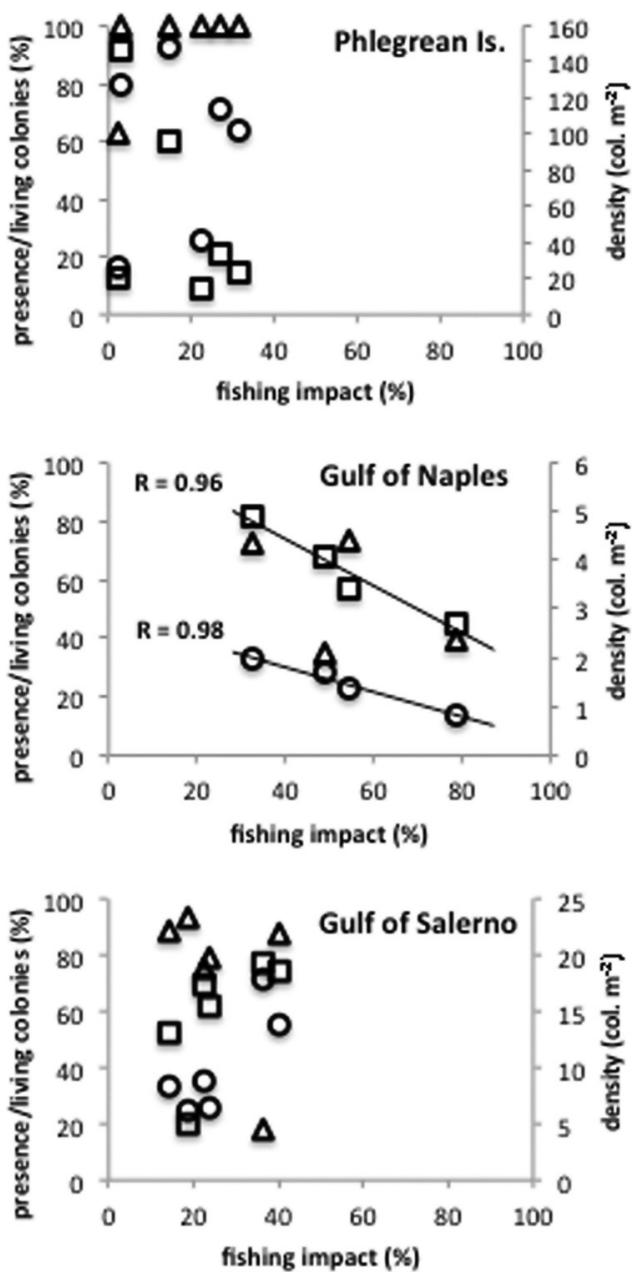

Figure 2. Presence of coral patches (expressed as \% of analysed frames including red coral colonies, circles), coral density (considering only the frames including patches, squares) and living colonies (expressed as \% of living colonies, triangles) vs fishing impact (expressed as \% of analysed frames including lost fishing gears) in the area of Phlegrean Islands, Gulf of Naples and Gulf of Salerno. A significant correlation was recorded between presence and density vs impact only in the Gulf of Naples.

dead colonies was observed (Figure 1b). Most of the sites showing serious mortalities are located in the innermost area of the Gulf of Naples (for example, on the Pampano shoal, $73 \%$ of the rare colonies were dead). However, the most dramatic mortality was recorded at Li Galli Islands (Amalfi coast), where about $82 \%$ of the colonies within $90-110 \mathrm{~m}$ depth (Table I, Figure $1 \mathrm{~b}$ ) were diseased (partially covered by living coenenchyme) or dead (completely deprived of coenenchyme) (Figure 4a-d).

The mortality mainly struck large colonies (Figure 4a), while young ones, with a maximal height not exceeding $4 \mathrm{~cm}$ and only one or two branches, were generally covered by coenenchyme (Figure 4e). The largest collected dead colony, with 

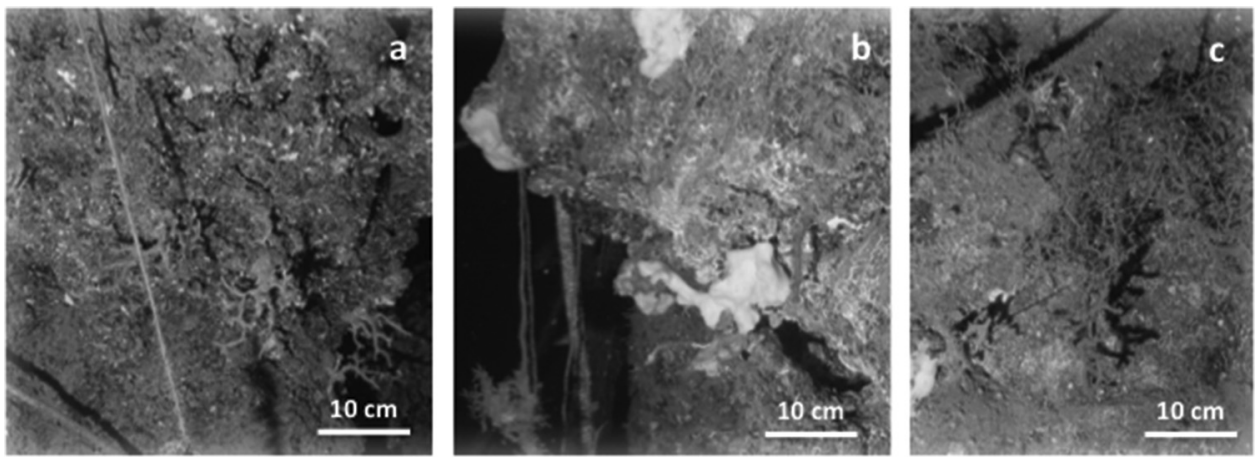

Figure 3. Lost fishing gear's impact on the red coral populations inside the Gulf of Naples. a, a lost line close to a group of dead red coral colonies; b, cables and a trammel net floating close to an old dead colony base and to an unbranched living one; c, a portion of a trammel net entangled on a living colony of red coral.
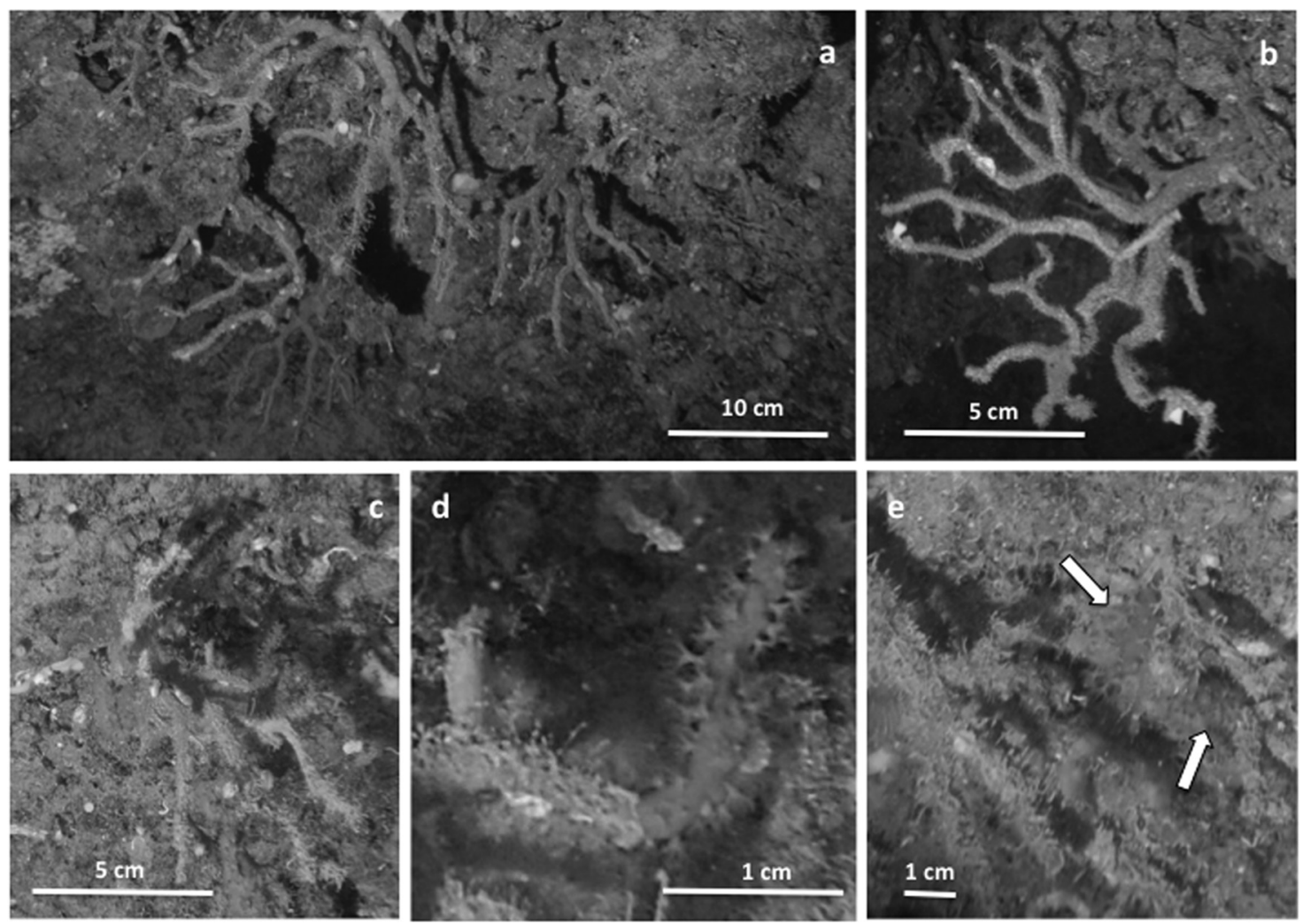

Figure 4. Red coral mass mortality at Li Galli Islands. a, image of the population showing only one colony with living coenenchyme. Dead colonies are recognisable for the absence of coenenchyme, while the scleraxis is covered by a turf of benthic organisms, mainly hydrozoans. b, a whole large dead colony in situ, demonstrating the absence of mechanical injuries. c, a diseased colony with a large part of the branches deprived of coenenchyme found only at the apex of the ramifications. $d$, enlargement of the previous image, showing the expanded polyps arising from the living portion. e, arrows indicate two $1-2 \mathrm{~cm}$ high recruits with expanded polyps.

a basal diameter of about $20 \mathrm{~mm}$, was estimated to be around 70 years old, on the basis of the annual growth rings according to Marschal et al. (2004).

The size frequency distribution of the height of the entire population was unimodal and symmetric, with the mode in the size class $6-8 \mathrm{~cm}$ (Figure 5). Inside this distribution, healthy colonies were mainly included in the size classes $0-2$ and $2-4 \mathrm{~cm}$ (Figure 5).

Dead colonies were found intact, attached to their substrate with the exposed calcareous scleraxis (Figure 4a) covered by a large amount of epibionts 


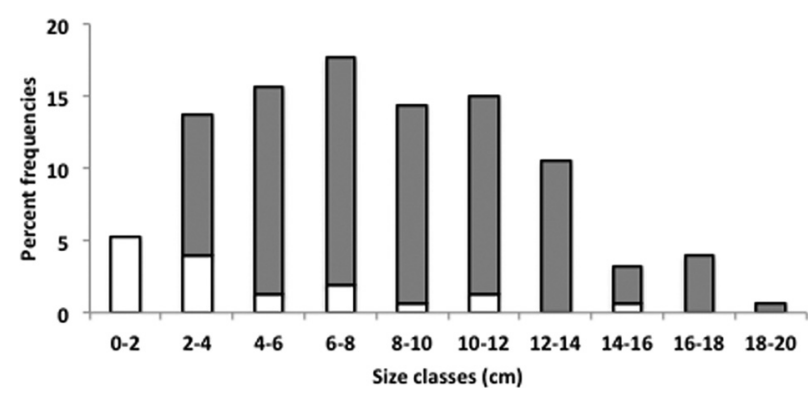

Figure 5. Size-frequency distribution of the height of the colonies of the red coral population of Li Galli Islands. White portions, living colonies; grey portions, dead colonies.

(Figure 6a-c), including a dense turf of small hydroids (Figure 4a-b), several corallites of the scleractinian Caryophyllia sp. (Figure 6b) and a net of serpulids (Figure 6c). All the collected colonies were infested by the boring sponge Spiroxya laevispira (Topsent, 1898), producing large sub-spherical or irregular boring chambers at the base of the main stem of the colonies (Figure $6 \mathrm{~d}-\mathrm{e}$ ).

\section{Discussion}

These data represent the first analysis, after more than a century, of one of the most exploited rocky bottoms in the Mediterranean Sea, where red coral has been collected for centuries. Although a quantitative comparison among historical (Mazzarelli \& Mazzarelli 1918) and present data is impossible, it is relevant that an area where the coral fishing was economically sustainable 100 years ago is now almost completely deprived of red coral, as demonstrated by data obtained from the seven re-visited sites in the inner part of the Gulf of Naples.

The dramatic reduction of the red coral populations induces suspicion of a more extensive degradation of the entire deep community. This process is indeed alarming, considering that for at least 150 years, the Gulf of Naples was the main site for the study of biodiversity of the Mediterranean Sea, as evidenced by the 40 monographs of Flora Fauna und der Neaples published over a century, by the Zoological Station "Anton Dohrn".

Based on present data, the main healthy red coral banks within the gulfs of Naples and Salerno are now limited to the Ischia and Procida Islands cliffs (Gambi et al. 2003) that are partially included in the "Regno di Nettuno" Marine Protected Area (MPA), and in most of the sites of the Amalfi coast. These populations appear in good condition: red coral occupancy, density and average percentage of living colonies is significantly higher, while the number of frames showing lost fishing gear is lower. In contrast, the populations
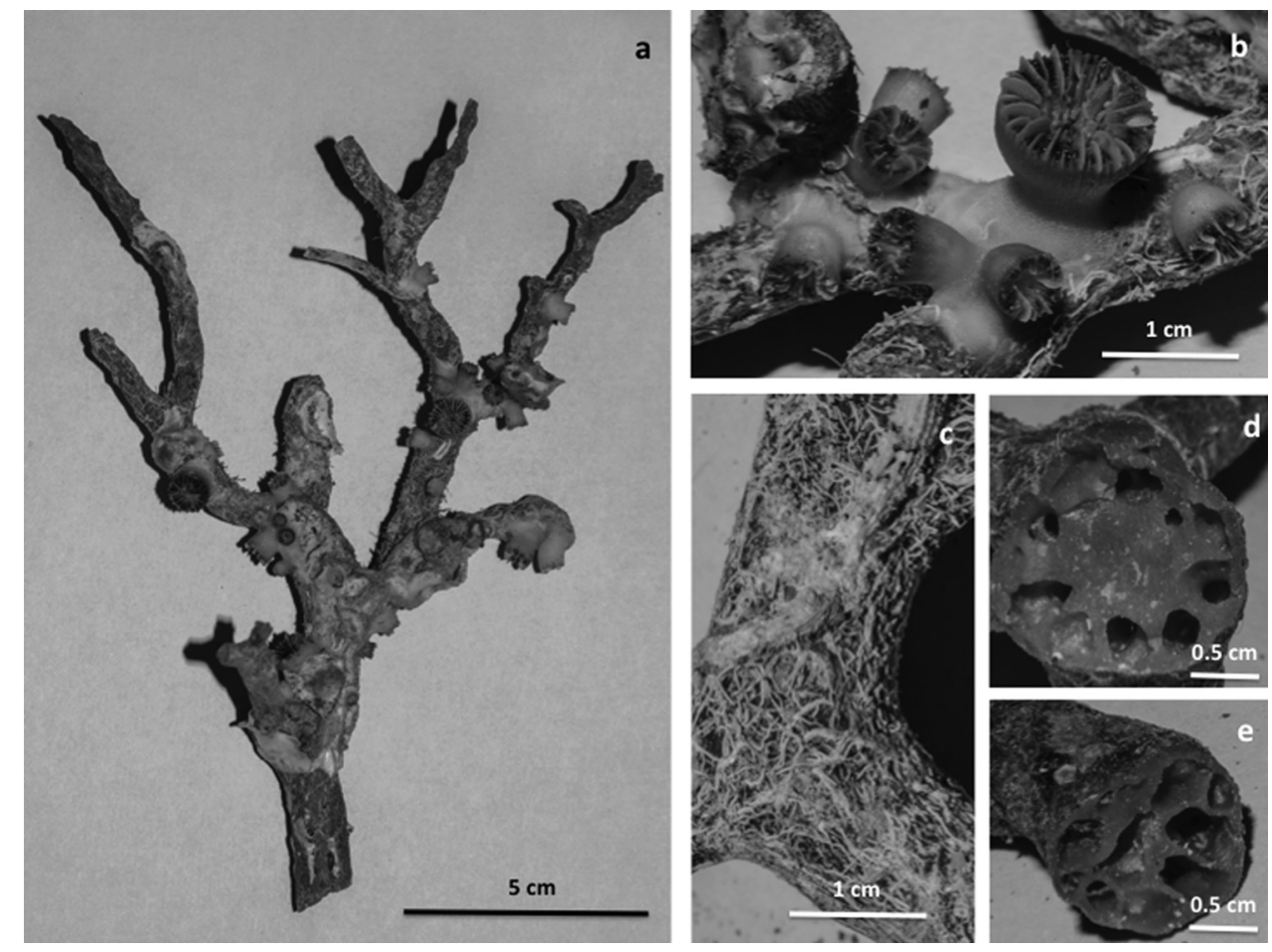

Figure 6. a, Large dead colony of Corallium rubrum collected at Li Galli Islands. The scleraxis is widely colonised by scleractinians of two sizes (b) and by a net of serpulid tubes (c). The basal portion of the scleraxis shows the typical boring chambers of Spiroxya laevispira (d, e). 
of the inner part of the Gulf of Naples, between 110 $140 \mathrm{~m}$ depth, are evidently in a suffering condition, being characterised by significatively lower densities (< 5 colonies $\mathrm{m}^{-2}$ ) and a higher incidence of diseased or dead colonies. These conditions, after centuries of exploitation of the banks, are also probably related to an increase in water pollution and sedimentation due to the strong urban and industrial development of the area. Moreover, the complex geomorphology (Aiello et al. 2001) and dynamics of the Gulf favour water stagnation and enhance pollution and sedimentation rates (De Maio et al. 1985; Cianelli et al. 2011). In fact, when the Tyrrhenian current moves southeastward, the outer part of the Gulf of Naples shows a cyclonic gyre, while the inner part remains isolated, forming anticyclonic gyres (De Maio et al. 1985; Cianelli et al. 2011) that prevent the circulation of the coastal waters.

Additionally, our survey has documented a significant impact of fishing activities on the deep rocky communities, especially on the shoals in the proximity of the city of Naples, as indicated by the large amount of lost fishing gear observed on the explored sea bed. This kind of pressure, unfortunately very common in several Tyrrhenian fishing grounds, negatively impacts benthic communities by eradicating large arborescent colonies or by inducing diseases due to mechanical friction (Bo et al. 2014).

A peculiar situation has been recorded at Li Galli Island, a well-known population already reported by Colombo in 1887, where widespread red coral mortality has been observed. This episode is particularly interesting, since it occurred below $90 \mathrm{~m}$ depth, in an area not subjected to strong urban pollution. The Li Galli Islands mortality episode, involving pluridecennial colonies, was probably a single event in the last century, and opens new perspectives in determining the causes of deep water mortalities, beyond the invoked effects due to global warming (Garrabou et al. 2009).

A tentative determination of when this mortality occurred has been made on the basis of the size of the coral recruits. While all the large colonies were struck, the young ones, settled after the event and not exceeding $4 \mathrm{~cm}$ high, were all in healthy condition. Considering that dead colonies remain in situ for a short span of time due to the boring sponge activity (Cerrano et al. 2001), it is reasonable to hypothesise that the episode occurred in the last few years. Moreover, since the growing rate in height of newborn corals is about $1 \mathrm{~cm} \mathrm{y}^{-1}$ (Cattaneo-Vietti \& Bavestrello 1994), it is possible to estimate their age to be around 2-4 years. These data support the hypothesis that the described mortality occurred between 2 and 4 years before our observations and, therefore, overlapped the lethal episodes involving sea fans that occurred in the same area in 20082009 at shallower depths (Gambi et al. 2010; Gambi \& Barbieri 2012).

Understanding the causes of this mortality is a difficult task. A human impact seems unlikely, although fishermen exploited this bank for centuries (Colombo 1887). The occurrence of entire dead colonies in situ, without evident ruptures of branches, excludes, in fact, mechanical injuries, such as those produced by fishing activities. Neither can the mortality simply be attributed to pollution or thermal anomalies related to global changes (Cerrano et al. 2000; Coma et al. 2009; Garrabou et al. 2009), owing to the offshore location of the site and the depth at which is situated.

So far, no significant mortalities have ever been recorded below the summer thermocline, at a depth range characterised by seawater temperatures generally considered stable throughout the year. In the Mediterranean Sea, only Rivoire (1987, 1991) described a partial gorgonian and red coral mortality off the Provence coastline at a depth ranging from 80 to $160 \mathrm{~m}$, tentatively attributed to polluted waters driven by dominant currents.

In the Gulf of Naples and along the Campanian coast, several local mass mortalities of gorgonians were recorded repeatedly in the late summers of 1999, 2002, 2005, 2008 and 2009. The Eunicella cavolinii (Koch, 1887) populations in the marine cave Grotta Azzurra at Palinuro Cape were drastically reduced, as well as Eunicella singularis (Esper, 1791), E. cavolinii and Paramuricea clavata (Risso, 1826) populations along the coast of the island of Ischia and Punta Campanella (Gambi et al. 2006; Cigliano \& Gambi 2007; Sbrescia et al. 2008; Gambi et al. 2010; Gambi \& Barbieri 2012). In all these cases, mortalities were recorded at a maximal depth of $30-40 \mathrm{~m}$ and were related to water-surface temperature anomalies that occurred in those summers.

The temporal coincidence hypothesised between the deep red coral mortality and the shallow-water episodes in the study area induces a reconsideration of the relationships between shallow- and deep-water layers. The calcareous coast of the Sorrentine Peninsula, facing the $\mathrm{Li}$ Galli Islands, is an area exposed to landslides (Calcaterra \& Santo 2004) and includes volcanoclastic deposits able to induce debris flows triggered by heavy or prolonged rainfalls along the steep slopes. Locally, these phenomena could produce turbidity currents and a consequent unusual drop of the summer thermocline.

An alternative hypothesis takes into consideration sudden warm water emissions, in an area characterised by important volcanic activities. The recently described mass mortality in the nearby Grotta 
Azzurra cave of Palinuro Cape, characterised by sulphur springs (Bianchi et al. 1995; Stüben et al. 1996), may support this hypothesis. Similar events are probably at the origin of the huge sub-fossil red coral banks (the so-called Sciacca red coral) discovered in 1875 in the Sicily Channel, which provided 14,000 tons of precious coral (Rajola 2012). The typical orange colour of the Sciacca coral would indeed be a consequence of prolonged exposure of the skeletons to hydrothermal emissions (Rajola 2012). The restricted action of a volcanic spring would also explain the limited extension of the dead bank of Li Galli, considering that some nearby explored locations still host living red coral.

Finally, we have to consider that all these environmental stressors may also induce infections by pathogenic microorganisms (Martin et al. 2002; Vezzulli et al. 2010; Pasquale et al. 2011), which may extend from the shallow populations to the deepest colonies. In this case, it seems that the stress is higher for larger colonies than smaller ones, the latter exhibiting a higher chance of survival. A higher sensitivity of the larger colonies to stress was shown in the E. cavolinii and P. clavata populations of the Portofino Promontory, after the 1999 thermal crisis (Cerrano et al. 2005), as well as in the Grotta Azzurra cave (Palinuro Cape) (Gambi et al. 2010; Gambi \& Barbieri 2012). It is very likely that reproductive effort could affect the sensitivity of the colonies towards environmental stressors. Considering that red coral reaches its first reproductive age when the colony is $3 \mathrm{~cm}$ high (Santangelo et al. 2003, 2004; Torrents et al. 2005; Gallmetzer et al. 2010), we can assume that smaller colonies, not involved in reproductive efforts, are less sensitive.

The deep red coral mortalities observed in the gulfs of Naples and Salerno might then be attributed to different causes: in a semi-closed basin, such as the Gulf of Naples, with relatively modest hydrodynamic exchanges, water pollution is very likely the primary cause, whether it is important not to underestimate the fishing pressure, likely reducing the chance of recovery of these populations. On the contrary, at Li Galli Islands, some occasional events such as turbidity currents or thermal springs may have caused a very localised die-off, the effects of which could be reduced, in the long term, by recruitment.

\section{Acknowledgements}

We would like to thank the crew members of $\mathrm{R} / \mathrm{V}$ Astrea for their help in the field. Warm thanks go to Rosaria and Enrico Gargiulo (Sorrento) for their kind help in collecting information about the red coral banks inside the Gulf of Naples. We thank also the referees for their useful suggestions. This work was financed by: Ministero dell'Ambiente e della Tutela del Territorio e del Mare (Project 2010, Red Coral), CoCoNet Project ["Towards COast to COast NETworks of marine protected areas (from the shore to the high and deep sea), coupled with sea-based wind energy potential"], 7th Framework Programme, EU, RITMARE Project (La ricerca italiana per il mare), Cofinanziamento di Progetti di Ricerca d'Interesse Nazionale (COFIN-PRIN) 2011-2012.

\section{References}

Aiello G, Budillon V, Cristofalo G, d'Argenio B, de Alteriis G, De Lauro M, Ferraro L, Marsella E, Pelosi N, Sacchi M, Toniello R. 2001. Main geology and morphobathymetry in the Bay of Naples (South-Eastern Tyrrenian Sea, Italy). In: Faranda FM, Guglielmo L, Spezie G, editors. Mediterranean ecosystems: structure and processes. Italia: Springer Verlag. pp. 235-240.

Ballesteros E. 2006. Mediterranean coralligenous assemblages: A synthesis of present knowledge. Oceanography and Marine Biology: An Annual Review 44:123-195.

Bally M, Garrabou J. 2007. Thermodependent bacterial pathogens and mass mortalities in temperate benthic communities: A new case of emerging disease linked to climate change. Global Change Biology 13:2078-2088. doi:10.1111/j.13652486.2007.01423.x.

Bavestrello G, Bertone S, Cattaneo-Vietti R, Cerrano C, Gaino E, Zanzi D. 1994. Mass mortality of Paramuricea clavata (Anthozoa: Cnidaria) on Portofino Promontory cliffs (Ligurian Sea). Marine Life 4:15-19.

Bianchi CN, Cinelli F, Morri C. 1995. The biology of a submarine cave with sulphur springs (the "Grotta Azzurra" of Capo Palinuro, southern Italy). Cave Diving 6:10-13.

Bo M, Bava S, Canese S, Angiolillo $M$, Cattaneo-Vietti R, Bavestrello G. 2014. Fishing impact on deep Mediterranean rocky habitats as revealed by ROV investigation. Biological Conservation 171:167-176. doi:10.1016/j.biocon.2014.01.011.

Bruckner AW. 2009. Rate and extent of decline in Corallium (pink and red coral) populations: Existing data meet the requirements for a CITES Appendix II listing. Marine Ecology Progress Series 397:319-332. doi:10.3354/meps08110.

Bruckner AW. 2014. Advances in management of precious corals in the family Corallidae: Are new measures adequate? Current Opinion in Environmental Sustainability 7:1-8. doi:10.1016/j. cosust.2013.11.024.

Bussoletti E, Cottingham D, Bruckner AW, Roberts G, Sandulli R. 2010. Proceedings of the international workshop on red coral science Management, and trade: Lessons from the Mediterranean. Silver Spring MD: NOAA technical memorandum CRCP 13. $233 \mathrm{pp}$.

Calcaterra D, Santo A. 2004. The January 10, 1997 Pozzano landslide, Sorrento Peninsula, Italy. Engineering Geology 75:181-200. doi:10.1016/j.enggeo.2004.05.009.

Cattaneo-Vietti R, Bavestrello G. 1994. Four years rearing experiments on the Mediterranean red coral. Biologia Marina Mediterranea 1:413-420.

Cattaneo-Vietti R, Bavestrello G. 2010. Sustainable use and conservation of precious corals in the Mediterranean. In: Iwasaki N, editor. Biohistory of precious corals. Japan: Tokai University Press. 364 pp.

Cavolini F. 1785. Memorie per servire alla storia de' polipi. Napoli. 279 pp. 
Cerrano C, Arillo A, Azzini F, Calcinai B, Castellano L, Muti C, Valisano L, Zega G, Bavestrello G. 2005. Gorgonian population recovery after a mass mortality event. Aquatic Conservation: Marine and Freshwater Ecosystems 15:147157. doi:10.1002/aqc.661.

Cerrano C, Bavestrello G, Bianchi CN, Calcinai B, Cattaneo-Vietti R, Morri C, Sarà M. 2001. The role of sponge bioerosion in Mediterranean coralligenous accretion. In: Faranda FM, Guglielmo L, Spezie G, editors. Mediterranean ecosystems: Structures and processes. Italia: Springer-Verlag. pp. 235-240.

Cerrano C, Bavestrello G, Bianchi CN, Cattaneo-Vietti R, Bava S, Morganti C, Morri C, Picco P, Sara G, Schiaparelli S, Siccardi A, Sponga F. 2000. A catastrophic mass-mortality episode of gorgonians and other organisms in the Ligurian Sea (Northwestern Mediterranean), summer 1999. Ecology Letters 3:284-293. doi:10.1046/j.1461-0248.2000.00152.x.

Cerrano C, Danovaro R, Gambi C, Pusceddu A, Riva A, Schiaparelli S. 2010. Gold coral (Savalia savaglia) and gorgonian forests enhance benthic biodiversity and ecosystem functioning in the mesophotic zone. Biodiversity and Conservation 19:153-167. doi:10.1007/s10531-009-9712-5.

Cianelli D, Uttieri M, Buonocore B, Falco P, Zambardino G, Zambianchi E. 2011. Dynamics of a very special Mediterranean coastal area: The Gulf of Naples. In: Columbus F, editor. Mediterranean ecosystems: Dynamics, management \& conservation. New York: Nova Science Publishers, Inc. pp. 1-21.

Cigliano M, Gambi MC. 2007. The long hot summer. A further mortality event of gorgonians along the Phlaegrean Islands (Tyrrhenian Sea). Biologia Marina Mediterranea 14:292-293.

Colombo A. 1887. La fauna sottomarina del Golfo di Napoli. Roma: Rivista Marittima 20:1-107.

Coma R, Ribes M, Serrano E, Jimenez E, Salat J, Pascuals J. 2009. Global warming - enhanced stratification and mass mortality events in the Mediterranean. Proceedings of the National Academy of Sciences of the United States of America 106:6176-6181. doi:10.1073/pnas.0805801106.

Costa A. 1871. La pesca nel golfo di Napoli. Atti del Regio Istituto d'Incoraggiamento 7:1-96.

De Maio A, Moretti M, Sansone E, Spezie G, Vultaggio M. 1985. Outline of marine currents in the Bay of Naples and some considerations on pollutant transport. Il Nuovo Cimento C 8:955-969. doi:10.1007/BF02558022.

Gallmetzer I, Haselmair A, Velimirov B. 2010. Slow growth and early sexual maturity: Bane and boon for the red coral Corallium rubrum. Estuarine Coastal Shelf Sciences 90:1-10. doi:10.1016/j.ecss.2010.04.018.

Gambi MC, Barbieri F. 2012. Population structure of the gorgonian Eunicella cavolinii in the "Grotta Azzurra" cave off Palinuro, after the mass mortality event in 2008. [PDF] Biologia Marina Mediterranea 19:174-175.

Gambi MC, Barbieri F, Signorelli S, Saggiomo V. 2010. Mortality events along the Campania coast (Tyrrhenian Sea) in summers 2008 and 2009 and relation to thermal conditions. Biologia Marina Mediterranea 17:126-127.

Gambi MC, Cigliano M, Iacono B. 2006. Segnalazione di un evento di mortalità di gorgonacei lungo le coste delle isole di Ischia e Procida (Golfo di Napoli, Mar Tirreno). Biologia Marina Mediterranea 13:583-587.

Gambi MC, Dappiano M, Lanera P, Iacono B. 2003. Biodiversità e bionomia dei popolamenti bentonici dei fondi duri delle Isole Flegree (Ischia, Procida, Vivara - Golfo di Napoli). In: Gambi MC, De Lauro M, Jannuzzi F, editors. Ambiente Marino Costiero e Territorio delle Isole Flegree. Napoli: Liguori Editore. pp. 133-161.
Garrabou J, Coma R, Bensoussan N, Bally M, Chevaldonné P, Cigliano M, Diaz D, Harmelin JG, Gambi MC, Kersting DK, Ledoux JB, Lejeusne C, Linares C, Marschal C, Pérez T, Ribes M, Romano JC, Serrano E, Teixido N, Torrents O, Zabala M, Zuberer F, Cerrano C. 2009. Mass mortality in Northwestern Mediterranean rocky benthic communities: Effects of the 2003 heat wave. Global Change Biology 15:1090-1103. doi:10.1111/j.1365-2486.2008.01823.x.

Garrabou J, Perez T, Sartoretto S, Harmelin JG. 2001. Mass mortality event in red coral Corallium rubrum populations in the Provence region (France, NW Mediterranean). Marine Ecology Progress Series 217:263-272. doi:10.3354/meps217263.

Hammer Ø, Harper DAT, Ryan PD. 2001. PAST: Paleontological Statistics Software Package for Education and Data Analysis. Palaeontolia Electronica 4:1-9. Available: http://palaeo-electronica.org/2001_1/past/issue1_01.htm. Accessed Oct 20116.

Huete-Stauffer C, Vielmini I, Palma M, Navone A, Panzalis P, Vezzulli L, Misic C, Cerrano C. 2011. Paramuricea clavata (Anthozoa, Octocorallia) loss in the Marine Protected Area of Tavolara (Sardinia, Italy) due to a mass mortality event. Marine Ecology 32:107-116. doi:10.1111/j.1439-0485.2011.00429.x.

Lo Bianco S. 1909. Notizie biologiche riguardanti specialmente il periodo di maturità sessuale degli animali del golfo di Napoli. Mittelmeer Zoological Station Naples 19:35-761.

Marschal C, Garrabou J, Harmelin JG, Pichon M. 2004. A new method for measuring growth and age in the precious red coral Corallium rubrum (L). Coral Reefs 23:423-432. doi:10.1007/ s00338-004-0398-6.

Martin Y, Bonnefont JL, Chancerelle L. 2002. Gorgonians mass mortality during the 1999 late summer in French Mediterranean coastal waters: The bacterial hypothesis. Water Research 36:779-782. doi:10.1016/S0043-1354(01)00251-2.

Mazzarelli G. 1915. Risultati della campagna della R Nave "Volta" eseguita nell'estate 1913 per la esplorazione dei banchi di corallo dei mari italiani. Rivista di Pesca e Idrobiologia 10:1-47.

Mazzarelli G, Mazzarelli G. 1918. Prime indagini sui banchi di corallo del Golfo di Napoli. Annali di Idrobiologia e Pesca, Pavia 1:1-42.

Pasquale V, Guida M, Cennamo P, Mastascusa V, Greco M, Sandulli R. 2011. Cultivable heterotrophic bacteria associated to Corallium rubrum. Biologia Marina Mediterranea 18:274-275.

Perez T, Garrabou J, Sartoretto S, Harmelin JG, Francour P, Vacelet J. 2000. Mass mortality of marine invertebrates: An unprecedented event in the Northwestern Mediterranean. Comptes Rendus de l'Académie des Science Paris, Science de la Vie 323:853-865.

Rajola G. 2012. Mistero Sciacca: Storia di un corallo di altri tempi. Italy: Edizioni Scientifiche e Artistiche. pp. 1-258.

Rivoire G. 1987. Existence de champs de corail rouge et de gorgones mort en profondeur, entre Cassis et Nice. Rapport destiné à la Direction des Affair Maritims de Mediterranée, Lab Ecol Benthos, Univ Aix-Marseille II, France:1-16.

Rivoire G. 1991. Mortalitè de corail et de gorgones en profondeur au large des cotes provencales. In: Bourdouresque CF, Avon $\mathrm{M}$, Gravez V, editors. Les especies marines a proteger en Mediterranee. France: GIS Posidonies. pp. 53-59.

Rossi S, Tsounis G, Orejas C, Padrón T, Gili JM, Bramanti L, Teixidó N, Gutt J. 2008. Survey of deep-dwelling red coral (Corallium rubrum) populations at Cap de Creus (NW Mediterranean). Marine Biology 154:533-545. doi:10.1007/ s00227-008-0947-6.

Santangelo G, Carletti E, Maggi E, Bramanti L. 2003. Reproduction and population sexual structure of the 
overexploited Mediterranean red coral Corallium rubrum. Marine Ecology Progress Series 248:99-108. doi:10.3354/ meps 248099 .

Santangelo G, Maggi E, Bramanti L, Bongiorni L. 2004. Demography of the over-exploited Mediterranean red coral, Corallium rubrum (L. 1758). Scientia Marina 68:199-204.

Sbrescia L, Russo M, Di Stefano F, Russo GF. 2008. Analisi delle popolazioni di gorgonie dell'AMP di Punta Campanella dopo eventi di moria di massa. Atti Associazione Italiana di Oceanologia e Limnologia 19:449-457.

Schiaparelli S, Castellano M, Povero P, Sartoni G, Cattaneo-Vietti R. 2007. A benthic mucilage event in North-Western Mediterranean Sea and its possible relationships with the summer 2003 European heatwave: Short term effects on littoral rocky assemblages. Marine Ecology - An Evolutionary Perspective 28:341-353. doi:10.1111/j.1439-0485.2007.00155.x.

Stüben D, Sedwick P, Colantoni P. 1996. Geochemistry of submarine warm springs in the limestone cavern of Grotta
Azzurra, Capo Palinuro, Italy: Evidence for mixing-zone dolomitisation. Chemical Geology 131:113-125. doi:10.1016/ 0009-2541(96)00029-0.

Torrents O, Garrabou J, Marschal C, Harmelin JG. 2005. Age and size at first reproduction in the commercially exploited red coral Corallium rubrum (L.) in the Marseilles area (France, NW Mediterranean). Biological Conservation 121:391-397. doi:10.1016/j.biocon.2004.05.010.

Tsounis G, Rossi S, Grigg RW, Santangelo G, Bramanti L, Gili JM, Gibson, R, Atkinson, R, Gordon, J. 2010. The exploitation and conservation of precious corals. Oceanography and Marine Biology: An Annual Review 48:161-211. doi:10.1201/ EBK1439821169-c3.

Vezzulli L, Previati M, Pruzzo C, Marchese A, Bourne DG, Cerrano C, Consortium V. 2010. Vibrio infections triggering mass mortality events in a warming Mediterranean Sea. Environmental Microbiology 12:2007-2019. doi:10.1111/ j.1462-2920.2010.02209.x. 